УДК 634.723 .1

(C) 2016

Кучер М. Ф., кандидат сільськогосподарських наук,

Постоленко Л. В., молодщий науковий співробітник

(науковий керівник - кандидат сільськогосподарських наук М. Ф. Кучер)

Інститут помології ім. Л. П. Симиренка НААН України

\title{
ОЦНКА ВПЛИВУ МУЛЬЧУВАННЯ ПРИКУЩОВИХ СМУГ І ЗРОШЕННЯ НА РІСТ ТА ПРОДУКТИВНІСТЬ СМОРОДИНИ ЧОРНОЇ
}

\section{Рецензент - кандидат сільськогосподарських наук В. М. Гибало}

Наведено результати очінки сумарного однорічного приросту рослин сортів смородини чорної та проведено оцінку їхньої продуктивності в разі мульчування прикущзових смуг та використання зрошення. В результаті проведення досліджень встановлено, щзо у всіх досліджуваних сортів використання мульчуючих матеріалів у прикущьових смугах сприяло істотному збільшенню сумарного однорічного приросту як y варіантах з використанням краплинного зрошення, так $i$ без зрошення на фоні контрольного варіанту чорний пар. Найвищу продуктивність насаджень смородини чорної забезпечуе сумісне використання краплинного зрошення та мульчуючих матеріалів.

Ключові слова: чорна смородина, сорт, ріст, приріст, мульчування, зрошення, кущ.

Постановка проблеми. Смородина чорна (Ribes nigrum L.) належить до цінних ягідних культур. За вмістом вітамінів вона $\epsilon$ найбагатшою серед ягідних культур, які вирощуються в грунтово-кліматичних умовах України. Так, вміст вітаміну С в ягодах знаходиться в межах від 90 до 300 мг на 100 г сирої маси. Присутні в них також вітаміни А (каротин), $\mathrm{B}_{1}$ (тіамін), $\mathrm{K}_{1}, \mathrm{P}$ (цитрин), $\mathrm{PP}_{1}$, кумарини, фурокумарини, цукри, азотні кислоти, ефірні олії, ароматичні, а також неорганічні речовини, в тому числі калій, кальцій, магній, кремній, фосфор $[3,7,8,11]$.

Завдяки сучасним селекційним досягненням біологічний потенціал урожайності нових сортів смородини чорної оцінюється в 60 т/га. Проте фактична іiї урожайність перебуває ще на досить низькому рівні й у багатьох випадках не перевищує 3-4 т/га. Така низька реалізація потенціалу продуктивності, 3 одного боку, пов'язана 3 відсутністю у виробництві сортів, які мають високу стійкість до хвороб та шкідників, а також до пошкодження весняними заморозками квіток і зав'язі, що значно знижують урожай, а з іншого боку, низький рівень агротехніки не дає змогу сортам реалізувати свій потенціал [1].

Аналіз останніх досліджень i публікацій, у яких започатковано розв'язання проблеми.
Система утримання грунту є одним із найважливіших агротехнічних прийомів, особливо в пристовбурній смузі, де розміщується основна частина кореневої системи плодових рослин i бур'яни завдають максимальної шкоди, оскільки становлять конкуренцію плодовим рослинам за споживання вологи і мінеральних елементів, сприяють розвитку хвороб, знижують урожай $\mathrm{i}$ його якість [2].

Серед агротехнічних заходів, які сприяють підвищенню продуктивності насаджень смородини чорної важливе місце належить використанню зрошення та мульчуючих матеріалів у прикущових смугах.

Зрошення збільшує приріст пагонів, підвищує кількість бруньок на них, стимулюючи ріст молодих пагонів, дає змогу більш тривалий час підтримувати рослину у стані відносної молодості, що позитивно впливає на врожай ягід [5].

Доцільність застосування різних видів мульчуючих матеріалів вивчала низка вчених (Р. М. Буцик, I. I. Хоменко, В. В. Волошина та ін.), але ці питання в подальшому потребують ще детального вивчення [9].

Метою досліджень $\epsilon$ вивчення закономірностей росту, розвитку нових сортів смородини чорної та оцінка їх продуктивності в разі використання краплинного зрошення за різних систем утримання грунту у прикущових смугах та визначення найбільш ефективних елементів технології вирощування культури.

Вирішувалися такі завдання: дослідити особливості росту рослин чорної смородини та іiі продуктивність, визначити основні фактори впливу на ці показники.

Матеріали та методика досліджень. Експериментальну частину роботи було виконано в Інституті помології ім. Л. П. Симиренка НААН України протягом 2010-2015 років.

Об'єкт досліджень - комплекс господарськобіологічних ознак сортів культури, що вивчається, під час вирощування їх із застосуванням різних елементів технології. 


\section{СІЛЬСЬКЕ ГОСПОДАРСТВО. РОСЛИННИЦТВО}

Матеріалом для досліджень слугували сорти смородини чорної Пам'ять Правика (к), Муза, Мелодія, а також елітна гібридна форма № 1060 (Пегас), з використанням варіантів мульчування - чорний пар (к), агроволокно (чорного кольору), плівка (темного кольору), тирса, солома, хвоя та краплинного зрошення. Схема садіння рослин - 3х0,75 м. Повторність досліду триразова. Грунт у міжряддях утримували під чорним паром. Дослідження виконували згідно із загальноприйнятими методиками $[4,6,10]$.

Результати досліджень. У результаті проведення досліджень встановлено, що у всіх досліджуваних сортів використання мульчуючих матеріалів у прикущових смугах сприяло істотному збільшенню сумарного однорічного приросту як у варіантах 3 використанням краплинного зрошення, так і без зрошення на фоні контрольного варіанту - чорний пар (табл. 1).

Найбільший сумарний однорічний приріст під час використання зрошення та без нього відмічено у випадку використання в якості мульчуючого матеріалу агроволокно. Використання зрошення у насадженнях досліджуваних сортів без застосування мульчі збільшувало сумарний однорічний приріст на 3,0-3,5 м/кущ. Сумісне використання зрошення та мульчуючих матеріалів забезпечило збільшення однорічного приросту на кущах досліджуваних сортів у межах 2,5-3,2 м порівняно 3 аналогічними варіантами без зрошення та на 5,1-6,4 м порівняно 3 варіантом без зрошення та на 5,0-6,4 м порівняно 3 варіантом без використання зрошення і мульчуючих матеріалів. Урожайність досліджуваних сортів смородини в середньому за 2011-2015 роки в контрольному варіанті без зрошення у випадку системи утримання грунту чорний пар становила: Пам'ять Правика - 5,6 т/га, Муза - 6,2 т/га, Мелодія - 6,0 т/га, №1060 (Пегас) - 5,2 т/га (табл. 2). Використання мульчуючих матеріалів у прикущових смугах забезпечило підвищення урожайності у всіх досліджуваних сортів.

Так, використання мульчуючого матеріалу агроволокно у прикущових смугах забезпечило підвищення урожайності у сортів: Пам'ять Правика - на 3,4 т/га, Муза - на 4,2 т/га, Мелодія на 3,6 т/га, №1060 (Пегас) - на 3,1 т/га. Мульчування прикущових смуг плівкою сприяло збільшенню врожаю у сортів: Пам'ять Правика на 1,3 т/га, Муза - на 0,9 т/га, Мелодія - на 1,1 т/га, №1060 (Пегас) - на 0,9 т/га. Використання мульчуючого матеріалу тирси у прикущових смугах забезпечило підвищення урожайності по досліджуваних сортах смородини: Пам'ять Правика на 1,6 т/га, Муза - на 1,8 т/га, Мелодія - на 1,9 т/га, №1060
(Пегас) - на 2,1 т/га. Підвищення урожайності в разі мульчування прикущових смуг соломою по досліджуваних сортах смородини становило: Пам'ять Правика на 2,6 т/га, Муза - на 3,0 т/га, Мелодія - на 2,7 т/га, №1060 (Пегас) - на 2,4 т/га. Використання мульчуючого матеріалу хвої у прикущових смугах забезпечило підвищення урожайності по досліджуваних сортах смородини Пам'ять Правика на 1,9 т/га, Муза - 1,6 т/га, Мелодія - 2,1 т/га, №1060 (Пегас) - 1,3 т/га.

Мульчуючі матеріали у прикущових смугах сприяли поліпшенню водного режиму грунту і забезпечили підвищення урожайності, в середньому за 2011-2015 роки спостережень по досліджуваних сортах смородини найвищий приріст урожайності від 3,1 т/га (№1060 (Пегас)) до 4,2 т/га (Муза) у варіантах 3 мульчуванням прикущових смуг агроволокном.

У середньому за 2011-2015 роки врожайність досліджуваних сортів смородини із застосуванням краплинного зрошення в контрольному варіанті за системи утримання грунту чорний пар становила по сортах: Пам'ять Правика - 8,5 т/га, Муза 10,1 т/га, Мелодія - 9,7 т/га, №1060 (Пегас) - 8,2 т/га, що дало приріст урожайності відповідно на 2,9, $3,9,3,7,3,0$ т/га.

Проаналізувавши варіанти вирощування чорної смородини з одночасним використанням мульчування та зрошення, констатуєм, що використання мульчування також збільшує урожайність досліджуваних сортів у порівнянні із контрольним варіантом без мульчування. Так, у випадку мульчування агроволокном на зрошенні середня врожайність за п'ять років у досліджуваних сортів становила: Пам'ять Правика - 12,2 т/га, Муза - 13,7 т/га, Мелодія - 14,0 т/га, №1060 (Пегас) - 11,2 т/га, що вище урожайності у контрольному варіанті без мульчування: Пам'ять Правика - на 3,7 т/га, Муза - на 3,6 т/га, Мелодія - на 4,3 т/га, №1060 (Пегас) - на 3,0 т/га. За роки досліджень у разі мульчування грунту плівкою i використання зрошення урожайність сортів становила: Пам'ять Правика - 10,2 т/га, Муза - 10,4 т/га, Мелодія 10,6 т/га, №1060 (Пегас) - 9,1 т/га, що більше урожайності у контрольному варіанті без мульчування: у сорту Пам'ять Правика - на 1,6 т/га, Музи - на 0,3 т/га, Мелодії і №1060 (Пегас) - на 0,9 т/га. Середня врожайність сортів за 20112015 роки в разі мульчування тирсою і використання зрошення становила: Пам'ять Правика 10,4 т/га, Муза - 11,0 т/га, Мелодія - 10,8 т/га, №1060 (Пегас) - 9,0 т/га, що вище урожайності на контролі: у сорту Пам'ять Правика - на 1,9 т/га, Музи - на 0,9 т/га, Мелодії - на 1,1 т/га, №1060 (Пегас) - на 3,1 т/га. 
СІЛЬСЬКЕ ГОСПОДАРСТВО. РОСЛИННИЦТВО

\section{1. Сумарний однорічний приріст рослин сортів смородини чорної під час мульчування прикуцових смуг та використання зрочення (середнє за 2012-2015 рр.)}

\begin{tabular}{|c|c|c|c|}
\hline \multirow{2}{*}{\multicolumn{2}{|c|}{ Варіант досліду }} & \multicolumn{2}{|c|}{ Сумарний однорічний приріст, м } \\
\hline & & без зрошення & на зрошенні \\
\hline \multicolumn{4}{|c|}{ Пам’ять Правика (контроль) } \\
\hline & Чорний пар (к) & 12,3 & 15,3 \\
\hline & Агроволокно & 14,8 & 17,4 \\
\hline & Плівка & 14,4 & 17,1 \\
\hline & Тирса & 14,5 & 17,0 \\
\hline & Солома & 14,6 & 17,2 \\
\hline & Хвоя & 14,5 & 16,9 \\
\hline \multicolumn{4}{|c|}{ Муза } \\
\hline & Чорний пар (к) & 12,1 & 15,4 \\
\hline & Агроволокно & 15,0 & 18,1 \\
\hline & Плівка & 14,5 & 17,6 \\
\hline & Тирса & 14,3 & 17,3 \\
\hline & Солома & 14,9 & 18,0 \\
\hline & Хвоя & 14,6 & 17,5 \\
\hline \multicolumn{4}{|c|}{ Мелодія } \\
\hline & Чорний пар (к) & 12,0 & 15,5 \\
\hline & Агроволокно & 15,2 & 18,4 \\
\hline & Плівка & 14,9 & 17,9 \\
\hline & Тирса & 15,0 & 17,8 \\
\hline & Солома & 15,2 & 18,1 \\
\hline & Хвоя & 14,9 & 17,8 \\
\hline \multicolumn{4}{|c|}{ №1060 (Пегас) } \\
\hline & Чорний пар (к) & 12,2 & 15,3 \\
\hline & Агроволокно & 15,1 & 17,9 \\
\hline & Плівка & 14,8 & 17,7 \\
\hline & Тирса & 14,9 & 17,6 \\
\hline & Солома & 15,0 & 18,0 \\
\hline & Хвоя & 14,9 & 17,9 \\
\hline \multirow[t]{2}{*}{$\mathrm{HIP}_{05}$} & $\begin{array}{c}\text { для типу мульчі } \\
\text { (фактор А) }\end{array}$ & 0,84 & 0,43 \\
\hline & для сорту (фактор В) & 0,69 & 0,35 \\
\hline
\end{tabular}

Під час мульчування грунту соломою із застосуванням краплинного зрошення середня врожайність по сортах становила: Пам'ять Правика - 10,7 т/га, Муза - 13,3 т/га, Мелодія - 12,5 т/га, №1060 (Пегас) - 10,4 т/га, що вище врожайності порівняно 3 контрольним варіантом без мульчування відповідно по сортах: Пам'ять Правика - на 2,2 т/га, Муза - на 3,2 т/га, Мелодія - на 2,8 т/га, №1060 (Пегас) - на $2,2 \mathrm{~T} / \mathrm{ra}$.

За роки досліджень мульчування хвоєю і використання зрошення підвищило врожайність по сортах: Пам'ять Правика - на 1,6 т/га, Муза, Мелодія і №1060 (Пегас) - на 1,0 т/га. Сумісне використання краплинного зрошення та мульчуючих матеріалів сприяло найвищому збільшенню врожайності. Так, приріст врожайності в разі мульчування агроволок- ном і використання зрошення у досліджуваних сортів смородини становив: Пам'ять Правика $-6,7$ т/га, Муза - 7,5 т/га, Мелодія - 8,0 т/га, №1060 (Пегас) $6,1 \mathrm{т} /$ га, у випадку мульчування плівкою і використання зрошення: Пам'ять Правика і Мелодія 4,6 т/га, Муза - 4,2 т/га, №1060 (Пегас) - 4,0 т/га, в разі мульчування тирсою і використання зрошення: Пам'ять Правика - 4,9 т/га, Мелодія і Муза 4,8 т/га, №1060 (Пегас) - 3,8 т/га, під час мульчування соломою і використання зрошення - Пам'ять Правика - 5,2 т/га, Мелодія - 7,1 т/га, Муза 6,5 т/га, №1060 (Пегас) - 5,3 т/га, у разі мульчування хвоєю і використання зрошення - Пам'ять Правика та Мелодія - 4,6 т/га, Муза - 4,8 т/га, №1060 (Пегас) - 4,1 т/га, порівняно 3 варіантом без мульчування і без використання зрошення. 
СІЛЬСЬКЕ ГОСПОДАРСТВО. РОСЛИННИЦТВО

2. Середня врожайність сортів смородини чорної за 2011-2015 pp., m/2а

\begin{tabular}{|c|c|c|c|c|c|}
\hline \multirow{2}{*}{\multicolumn{2}{|c|}{ Варіанти досліду }} & Середня & $\begin{array}{l}\text { Приріст до } \\
\text { контролю }\end{array}$ & Середня & $\begin{array}{c}\text { Приріст до } \\
\text { контролю }\end{array}$ \\
\hline & & \multicolumn{2}{|c|}{ Без зрошення } & \multicolumn{2}{|c|}{ На зрошенні } \\
\hline \multicolumn{6}{|c|}{ Пам’ять Правика (контроль) } \\
\hline & $\begin{array}{l}\text { Чорний пар } \\
\text { (контроль) }\end{array}$ & 5,6 & - & 8,5 & - \\
\hline & Агроволокно & 8,9 & 3,4 & 12,2 & 3,7 \\
\hline & Плівка & 6,9 & 1,3 & 10,2 & 1,6 \\
\hline & Тирса & 7,1 & 1,6 & 10,4 & 1,9 \\
\hline & Солома & 8,2 & 2,6 & 10,7 & 2,2 \\
\hline & Хвоя & 7,5 & 1,9 & 10,1 & 1,6 \\
\hline \multicolumn{6}{|c|}{ Муза } \\
\hline & $\begin{array}{l}\text { Чорний пар } \\
\text { (контроль) }\end{array}$ & 6,2 & - & 10,1 & - \\
\hline & Агроволокно & 10,4 & 4,2 & 13,7 & 3,6 \\
\hline & Плівка & 7,1 & 0,9 & 10,4 & 0,3 \\
\hline & Тирса & 8,0 & 1,8 & 11,0 & 0,9 \\
\hline & Солома & 9,2 & 3,0 & 13,3 & 3,2 \\
\hline & Хвоя & 7,8 & 1,6 & 11,0 & 1,0 \\
\hline \multicolumn{6}{|c|}{ Мелодія } \\
\hline & $\begin{array}{l}\text { Чорний пар } \\
\text { (контроль) }\end{array}$ & 6,0 & - & 9,7 & - \\
\hline & Агроволокно & 9,6 & 3,6 & 14,0 & 4,3 \\
\hline & Плівка & 7,1 & 1,1 & 10,6 & 0,9 \\
\hline & Тирса & 7,9 & 1,9 & 10,8 & 1,1 \\
\hline & Солома & 8,7 & 2,7 & 12,5 & 2,8 \\
\hline & Хвоя & 8,1 & 2,1 & 10,6 & 0,9 \\
\hline \multicolumn{6}{|c|}{ №1060 (Пегас) } \\
\hline & $\begin{array}{l}\text { Чорний пар } \\
\text { (контроль) }\end{array}$ & 5,2 & - & 8,2 & - \\
\hline & Агроволокно & 8,2 & 3,1 & 11,2 & 3,0 \\
\hline & Плівка & 6,1 & 0,9 & 9,1 & 0,9 \\
\hline & Тирса & 7,2 & 2,1 & 9,0 & 0,8 \\
\hline & Солома & 7,6 & 2,4 & 10,4 & 2,2 \\
\hline & Хвоя & 6,5 & 1,3 & 9,2 & 1,0 \\
\hline \multirow{2}{*}{$\mathrm{HIP}_{05}$} & $\begin{array}{c}\text { для типу мульчі } \\
\text { (фактор А) }\end{array}$ & 0,56 & - & 1,24 & - \\
\hline & $\begin{array}{c}\text { для сорту } \\
\text { (фактор В) }\end{array}$ & 0,46 & - & 1,02 & - \\
\hline
\end{tabular}




\section{СІЛЬСЬКЕ ГОСПОДАРСТВО. РОСЛИННИЦТВО}

Висновок. Результати наших досліджень свідчать, що найвищий сумарний однорічний приріст забезпечує сумісне використання мульчування та зрошення. Кращими мульчуючими матеріалами $\epsilon$ агроволокно і солома як у варіантах без використання зрошення, так і за сумісного їх застосування. Сумісне використання зрошення $\mathrm{i}$ кращих мульчуючих матеріалів забезпечує збільшення сумарного однорічного приросту на кущах на 5,1-6,4 м порівняно з варіантом без використання зрошення і мульчі.

Мульчування прикущових смуг у насадженнях смородини, де відсутнє зрошення, сприяє підвищенню урожайності сортів на 0,9-4,2 т/га.

\section{БІБЛІОГРАФІЯ}

1. Коровин К.Л. Оценка сортов смородины черной по компонентам продуктивности / К. Л. Коровин. - Плодоводство : науч. тр. - РУП «Ин-т плодоводства»; [гл. ред. В. А. Самусь и др.]. - Самохваловичи, 2010. - Т. 22. - 364 с.

2. Леонович И. С. Рост и урожайность деревьев яблони на слаборослых клоновых подвоях при различных способах содержания почвы в приствольной полосе молодого сада / И. С. Леонович. - Плодоводство : науч. тр. - РУП «Ин-т плодоводства» ; [гл. ред. В. А. Самусь и др.]. - Самохваловичи, 2010. - Т. 22. - 364 с.

3. Марковський В. С. Ягідні культури в Україні : навч. посібник / В. С. Марковський, М. І. Бахмат. - Кам'янець-Подільський : ПП «Медобори2006», 2008. - 200 с.

4. Марковський B. C. Методика проведення агрономічних дослідів 3 ягідними культурами / В. С. Марковський, І. В. Завгородній. - К., 1993. $29 \mathrm{c}$.

5. Мочалов B. В. Некоторые особенности агротехники черной смородины в новосибирской области / В. В. Мочалов // Культура черной смородины. Доклады симпозиума. - М., 1972. С. 124-131.
Кращими мульчуючими матеріалами $є$ агроволокно i солома, використання яких підвищує врожайність сортів на 2,4-4,2 т/га.

Використання краплинного зрошення в насадженнях смородини чорної забезпечує збільшення урожайності досліджуваних сортів на 2,9-3,9 т/га залежно від біологічних особливостей сорту.

Найвищу продуктивність насаджень смородини чорної забезпечує сумісне використання краплинного зрошення та мульчуючих матеріалів. Під час застосування цих елементів технології вирощування врожайність досліджуваних сортів підвищується на 3,8-8,0 т/га. Кращими мульчуючими матеріалами є агроволокно і солома.

6. Методика проведення експертизи сортів плодово-ягідних, горіхоплідних культур та винограду / [ред. В. В. Волкодав]. - К. : Алефа, 2005. $232 \mathrm{c}$.

7. Постоленко Л. В. Вплив мульчування прикущових смуг i зрошення на продуктивність смородини чорної (Ribes nigrum L.) / Л. В. Постоленко // Садівництво. - К., 2015. - Вип. 70. C. 143-148.

8. Постоленко Л. В. Оцінка продуктивності та якості ягід нових сортів чорної смородини в сучасних технологіях вирощування / Л. В. Постоленко // Селекція та насінництво в умовах сучасного зерновиробництва. - Миронівка, 2013. C. 56.

9. Постоленко Л. В. Економічна ефективність вирощування смородини при мульчуванні прикущових смуг та використанні зрошення / Л. В. Постоленко // Вісник ХНАУ. - Серія «Економічні науки». - 2015. - №5. - С. 110-116.

10. Программа и методика сортоизучения плодовых, ягодных и орехоплодных культур. Мичуринск : ВНИИ садоводства, 1973. - 168 с.

11. Шеренговий П. 3. Моє життя - в моїх сортах / П. З. Шеренговий. - Вінниця, 2011. - 168 с. 